\title{
Microplastics Occurrence in Surface Waters and Sediments in Five River Mouths of Manila Bay
}

\author{
Ezra D. Osorio ${ }^{1 \star}$, Maria Antonia N. Tanchuling ${ }^{2}$ and Ma. Brida Lea D. Diola ${ }^{2}$ \\ ${ }^{1}$ Environmental Engineering Program, College of Engineering, University of the Philippines Diliman, Quezon City, Philippines, \\ ${ }^{2}$ Institute of Civil Engineering, College of Engineering, University of the Philippines Diliman, Quezon City, Philippines
}

OPEN ACCESS

Edited by:

Jennifer Drummond,

University of Birmingham,

United Kingdom

Reviewed by:

Veerasingam S.,

Qatar University, Qatar

An Liu,

Shenzhen University, China

${ }^{*}$ Correspondence:

Ezra D. Osorio

ezra.osorio@upd.edu.ph

Specialty section:

This article was submitted to

Toxicology, Pollution and the

Environment,

a section of the journal

Frontiers in Environmental Science

Received: 03 June 2021

Accepted: 16 August 2021 Published: 03 September 2021

Citation:

Osorio ED, Tanchuling MAN and Diola MBLD (2021) Microplastics Occurrence in Surface Waters and Sediments in Five River Mouths of

Manila Bay.

Front. Environ. Sci. 9:719274 doi: 10.3389/fenvs.2021.719274
Microplastics have been increasingly documented globally in numerous environmental compartments. However, little information exists in the Philippines despite the fact that the country is considered to be one of the largest contributors of plastics in oceans. This study, considered as one of the pioneering microplastic research, evaluated the abundance, distribution, and composition of microplastic pollution in the mouths of five rivers, namely Cañas, Meycauayan, Parañaque, Pasig and Tullahan, draining to Manila Bay. Surface water and sediments samples were collected, then passed through a stack of sieves with sizes from $2.36 \mathrm{~mm}$ at the top to $0.075 \mathrm{~mm}$ at the bottom. These samples were digested to remove organic matter, and salt solutions were added to allow the microplastics to float. Extracted particles were examined under a stereo microscope, and quantified and categorized into shape, size, color, and type. Results show that microplastics were present ubiquitously at all river mouths but with concentrations varying from 1,580 to 57,665 particles $/ \mathrm{m}^{3}$ (surface water) and 386 to 1,357 particles $/ \mathrm{kg}$ (dry sediment). Fragment was the most abundant shape, while white, blue, and transparent were the most prevalent colors. Fourier Transform Infrared Spectroscopy (FTIR) analysis revealed that polypropylene (PP), high and low-density polyethylene (high-density polyethylene and low-density polyethylene) and polystyrene were the main types of microplastics present in the river mouths.

Keywords: Manila bay, microplastics, plastic waste, sediment, surface water

\section{INTRODUCTION}

Microplastics are recently considered as an emerging pollutant, and these are divided into primary and secondary (Andrady, 2011; Wang et al., 2019). Primary microplastics are found in personal care products, cosmetics, medicines, and textiles as well as those by-products released from the use of plastic-related products such as tyre dust from running cars (Browne et al., 2011; Eriksen et al., 2013; Li et al., 2017; Wang et al., 2019; Suresh et al., 2020). Secondary microplastics are derived from the fragmentation of larger plastic and synthetic materials by processes such as UV degradation or machine washing (Andrady, 2011; GESAMP, 2015; Antunes et al., 2018). Microplastic contamination was first studied by Carpenter et al. (1972). Since then, many studies have documented the occurrence of microplastic contamination among the different bodies of water such as oceans (Anderson et al., 2016; Browne et al., 2011), estuaries (Browne et al., 2010; Lima et al., 2015; Zhao et al., 2014) freshwater bodies (Biginagwa et al. 2016; Free et al., 2014; Sanchez et al, 2014), and even in the remote arctic ice (Zarfle and Matthies, 2010; Hubard et al., 2014). 
There is hardly any monitoring of the microplastic contamination in the Philippines despite a study by Jambeck et al. (2015) that in 2010, the country has been identified as the third largest contributor of plastic wastes in the ocean globally and that about 1.01 million tonnes of plastic waste is mismanaged by the country in 2016 (Law, et al., 2020). Within the last 5 years, studies on microplastics contamination in the Philippines have been published which reported the occurrence of microplastics in surface water (Argota et al., 2018; Espiritu et al., 2019; Lumongsod and Tanchuling, 2019), marine sediments (Bucol et al., 2019; Espiritu et al., 2019; Esquinas et al., 2020; Kalnasa et al., 2019), and marine biota such as fishes (Bucol et al., 2019; Espiritu et al., 2019; Paler et al., 2021), mussels (Argamino and Janairo, 2016), and oysters (Espiritu et al., 2019). However, Galarpe et al. (2021) mentioned that there is a need for more macroplastic and microplastic research in the country to develop and support appropriate plastic regulation policies.

This research presents an overview and serves as a benchmark for the initial report on the microplastic contamination in the surface waters and sediments of the Manila Bay particularly in the mouths of its tributary rivers namely Cañas River, Meycauayan River, Parañaque River, Pasig River, and Tullahan River. One of the country's widely used, semi-closed inlet for various economic, industrial, and domestic activities of more than 16 million Filipinos, Manila Bay, is surrounded by densely populated areas including Metro Manila (PEMSEA and MBEMP TWG RRA, 2004). Due to intensive anthropogenic activities and mismanaged plastic waste and dumping within the watershed of the bay, the surface waters and sediments of the bay may accumulate high concentration of microplastics.

It is important to gather baseline information to minimize health and environmental risks posed by these microplastics in the future, specifically to the water quality of marine and freshwater environment, marine biota and even to human consumption and health.

\section{MATERIALS AND METHODS}

\section{Study Area}

Manila Bay (about $220 \mathrm{~km}$ coastline and 17,000 $\mathrm{km}^{2}$ drainage area) is a semi-enclosed marine inlet and its coastal water connects to the West Philippine Sea through a $16.7 \mathrm{~km}$ wide opening and surrounded by the National Capital Region and the municipalities of Cavite, Bulacan, Bataan, and Pampanga (Chang et al., 2009; Sia et al., 2009). It has 26 catchment areas including the river basins of Pasig and Pampanga, and a volume of approximately $31 \mathrm{~km}^{3}$ with an estimated depth of $17 \mathrm{~m}$ on an average (PEMSEA and MBEMP TWG-RRA, 2004). The bay is primarily used for international and local port and harbor, fishing ground, aquaculture, and other maritime activities (Prudente et al., 1994).

At present, it has deteriorating water quality because of intensified disposal and mismanagement of solid and human wastes (Chang et al., 2009; Sia et al., 2009). Despite the fact that a large amount of solid wastes was drained into the bay from the highly populated and industrialized area of Metro Manila and its surrounding provinces, data is lacking on the microplastic pollution in the bay. These solid wastes, specifically the plastic wastes would degrade into smaller pieces due to biological, chemical, and mechanical action, thus contributing to the microplastics in Manila Bay.

The study mainly focuses on the quantification and characterization of microplastics extracted from the five major river mouths namely Cañas River, Meycauayan River, Parañaque River, Pasig River, and Tullahan River draining to Manila Bay (Figure 1). These sampling areas were selected as these are the major river systems traversing through the National Capital region and the adjacent cities, which drain to Manila Bay. The mouths of these rivers are also accessible. Location and description of the study areas are presented in Table $\mathbf{1 .}$

\section{Collection of Samples}

All samples were collected from October 2018 to March 2019. Sampling was conducted once at each site with both surface water and sediments collected on the same day. Surface water samples were collected prior to sediments to avoid collecting suspended solids from the bottom of sampling sites. Water samples of $0.2 \mathrm{~m}^{3}$ with about $5 \mathrm{~m}$ away from the riverbanks were collected using a bucket from 0 to $12 \mathrm{~cm}$ below the surface of different points in the sampling area. The use of bucket for surface water sampling is also used by Su et al. (2016), Argota et al. (2018), Lumongsod and Tanchuling (2019) and Suresh et al. (2020) as an alternative to the manta net. The use of manta net was not applicable in the study areas due to the presence of macroplastics and large debris along the rivers.

Water from the bucket was poured unto the stacked stainless sieves with mesh sizes of 2.36-mm (No. 8), 1-mm (No. 18), 500- $\mu \mathrm{m}$ (No. 35), 250- $\mu \mathrm{m}$ (No. 60), 125- $\mu \mathrm{m}$ (No. 120) and $75-\mu \mathrm{m}$ (No. 200). Particles that are greater than $5 \mathrm{~mm}$ that were retained from the $2.36-\mathrm{mm}$ sieve were discarded. The used sieves were thoroughly rinsed with distilled water and left to dry for an hour. The retained particles in each sieve were transferred to their respective glass containers using steel tweezers and a brush.

For sediment sampling at each of the five sites, three sediment samples, were gathered using an Ekman grab sampler $\left(\sim 0.1 \mathrm{~m}^{2}\right)$ and a scoop with minimal disturbance. Two of these were collected from bank deposits about $10 \mathrm{~m}$ away from each other while the remaining one sample was taken from the main channel deposits of the river, The topmost $5 \mathrm{~cm}$ of the sediments was collected, stored in separate glass containers, and transported to the laboratory for processing together with the surface water samples.

Overall, there were five surface water samples and 15 sediment samples collected from five river mouths, with six subsamples each representing the particles retained in mesh sieves giving a total of 120 subsamples to be processed for digestion, density separation and filtration.

\section{Extraction of Microplastics}

The extraction of microplastics was conducted in accordance with previous studies (Peng et al., 2017; Su et al., 2016; Zhang, 2017), with some minor modifications. All samples from the 


\section{$\hat{\mathbf{N}}$ \\ Sampling Points at Manila Bay and their Current Condition during Sampling}
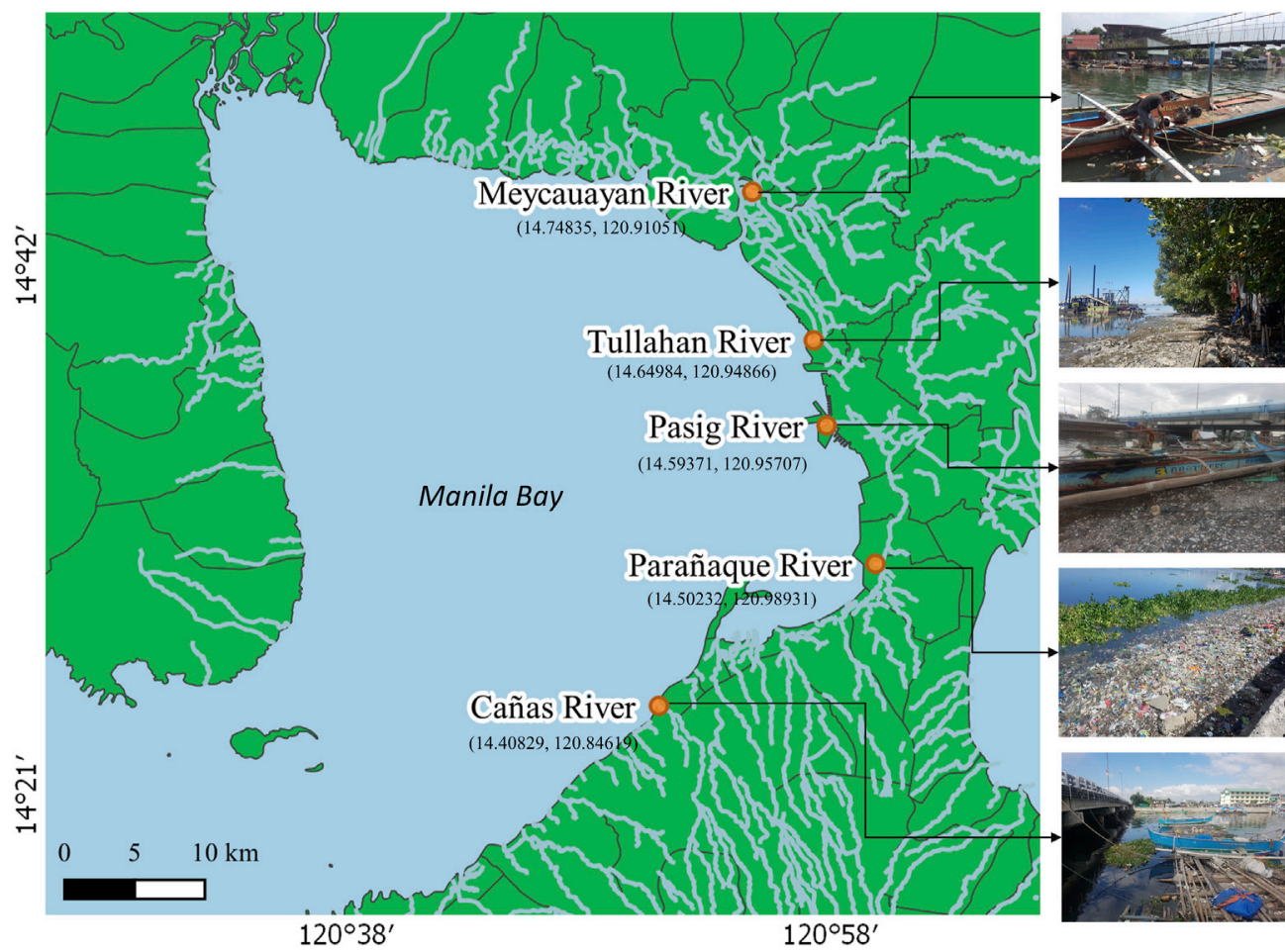

$120^{\circ} 58^{\prime}$

FIGURE 1 | Study areas and their condition during sampling.

TABLE 1 | Location and description of the study areas.

\begin{tabular}{|c|c|c|c|}
\hline Area & Latitude & Longitude & Description of the study area \\
\hline Cañas River & $14^{\circ} 24^{\prime} 29.84^{\prime \prime} \mathrm{N}$ & $120^{\circ} 50^{\prime} 46.28^{\prime \prime} \mathrm{E}$ & $\begin{array}{l}\text { In Province of Cavite; Along the river are residential homes mostly informal settler families with a population of } \\
50,717 \text { (2017) }\end{array}$ \\
\hline $\begin{array}{l}\text { Meycauayan } \\
\text { River }\end{array}$ & $14^{\circ} 44^{\prime} 54.06^{\prime \prime} \mathrm{N}$ & $120^{\circ} 54^{\prime} 37.84^{\prime \prime} \mathrm{E}$ & $\begin{array}{l}\text { In Province of Bulacan; One of the worst polluted rivers; Presence of plastic manufacturing industries within the } \\
\text { watershed of the river system }\end{array}$ \\
\hline Parañaque River & $14^{\circ} 30^{\prime} 8.35^{\prime \prime} \mathrm{N}$ & $120^{\circ} 59^{\prime} 21.52^{\prime \prime} \mathrm{E}$ & $\begin{array}{l}\text { In Metro Manila; Mouth of the river is beside the Las Piñas-Parañaque Critical Habitat and Ecotourism Area } \\
\text { (LPPCHEA), the only natural wetland sanctuary for birds in Metro Manila, and a seafood market. }\end{array}$ \\
\hline Pasig River & $14^{\circ} 35^{\prime} 37.36^{\prime \prime} \mathrm{N}$ & $120^{\circ} 57^{\prime} 25.45^{\prime \prime} \mathrm{E}$ & $\begin{array}{l}\text { In Metro Manila; One of the worst polluted rivers; Mouth of the river is surrounded by the Manila port and Baseco } \\
\text { Compound, a relocation site for informal settler families with a population of } 59,847 \text { (2015) }\end{array}$ \\
\hline Tullahan River & $14^{\circ} 38^{\prime} 59.42^{\prime \prime} \mathrm{N}$ & $120^{\circ} 56^{\prime} 55.18^{\prime \prime} \mathrm{E}$ & $\begin{array}{l}\text { In Metro Manila; Mouth of the river is surrounded by several facilities such as residential houses, elevated highways, } \\
\text { bus terminals, pumping station and bancas and canoes; Presence of plastic manufacturing industries within the } \\
\text { watershed }\end{array}$ \\
\hline
\end{tabular}

surface waters and sediments were oven-dried for $72 \mathrm{~h}$ with a temperature of $90^{\circ} \mathrm{C}$.

After drying, an aliquot of $70 \mathrm{~g}$ in each sediment sample was taken and poured through a stacked arrangement of $2.36-\mathrm{mm}$ (No. 8), 1-mm (No. 18), 500- $\mu \mathrm{m}$ (No. 35), 250- $\mu \mathrm{m}$ (No. 60), 125$\mu \mathrm{m}$ (No. 120) and 75- $\mu \mathrm{m}$ (No. 200) stainless mesh sieves. Sediments that passed through the $75-\mu \mathrm{m}$ sieve were discarded. The sediments in each sieve were transferred to their respective glass containers.

Wet peroxide oxidation (WPO) method was conducted to remove the organic matter present in all samples. At room temperature, $20 \mathrm{~cm}^{3}$ of both aqueous $0.05 \mathrm{M} \mathrm{Fe}$ (II) solution and $30 \% \mathrm{H}_{2} \mathrm{O}_{2}$ solution were added to the beaker containing collected solids in each size fraction (Yonkos et al., 2014; Masura et al., 2015). The samples were heated to $75^{\circ} \mathrm{C}$ and agitated at $200 \mathrm{rpm}$ using a magnetic stirring hotplate for at least $45 \mathrm{~min}$ (Ling et al., 2017). In instances where natural organic materials were still visible, an additional $20 \mathrm{~cm}^{3}$ of $30 \% \mathrm{H}_{2} \mathrm{O}_{2}$ was continually poured to the mixture until no gas bubbles were observed.

After all the visible organic matter were removed, density separation method was applied which allowed the high-density polymers to float. High-density sodium chloride $(\mathrm{NaCl} ; 1.202 \mathrm{~g} /$ $\mathrm{cm}^{3}$ ) was added to the mixtures of the samples (Galgani et al., 2013). $\mathrm{NaCl}$ solution is an effective medium that allows plastics such as PE $\left(0.91-0.97 \mathrm{~g} / \mathrm{cm}^{3}\right)$, PP $\left(0.94 \mathrm{~g} / \mathrm{cm}^{3}\right)$, PS $\left(1.05 \mathrm{~g} / \mathrm{cm}^{3}\right)$, 
TABLE 2 | Classification and categorization used for the collected microplastics.

\begin{tabular}{ll}
\hline Parameter & \multicolumn{1}{c}{ Categories } \\
\hline Shape & Fiber/line (elongated, fibrous, straight) \\
& Film (thin, soft, transparent) \\
& Fragment (hard, jagged, angular pieces) \\
& Foam (lightweight, porous, sponge-like) \\
& Pellet (hard, spherical, ovoid) \\
& Sheet (irregular flat, flexible) \\
& $75-<125 \mu \mathrm{m}$ \\
& $125-<250 \mu \mathrm{m}$ \\
Size & $250-<500 \mu \mathrm{m}$ \\
& $500-<1,000 \mu \mathrm{m}$ \\
& $1-<2.36 \mathrm{~mm}$ \\
& $2.36-<5 \mathrm{~mm}$ \\
& White \\
Color & Transparent \\
& Red \\
& Orange \\
& Yellow \\
Green & Blue \\
Black \\
Other Color
\end{tabular}

and PVC $\left(1.14 \mathrm{~g} / \mathrm{cm}^{3}\right)$ to float (Van Cauwenberghe et al., 2015). However, for sediment samples of 75 microns in which the floating particles could no longer be seen by the naked eye, zinc chloride $\left(\mathrm{ZnCl}_{2} ; 1.6 \mathrm{~g} / \mathrm{cm}^{3}\right)$ was added to ensure the separation of all common polymers (Van Cauwenberghe et al., 2015). The samples were mixed on a hot plate with a magnetic stirrer at $300 \mathrm{rpm}$ for about $15 \mathrm{~min}$ and were kept overnight covered with watch glass to observe clearance level wherein the microplastics floated and the other heavier particles settled down.

The supernatant water from the samples was transferred to another glass container, and then filtered using a Longer medium-high flow rate peristaltic pump with 47-mm Whatman ${ }^{\oplus}$ GF/C filters (pore size of $1 \mu \mathrm{m}$ ) to separate the microplastics.

\section{Identification and Quantification of Microplastics}

The extracted microplastics were examined and photographed using a 3.1-Megapixel CMOS camera connected to a ST-7045 Stereo microscope with magnification of $10 \mathrm{x}$ to $40 \mathrm{x}$. The length and area of microplastics were analyzed using the ToupView software equipped with the digital microscope calibrated to a standard.

All the particles were sorted according to their color, size, and shape (depends on physical characteristics) using the classification from previous studies (Free et al., 2014; Li et al., 2016) as indicated in Table 2.

Polymer make-up was determined using FTIR spectroscopy (Nicolet 6700 FTIR ATR spectrometer with a diamond accessory). Extracted particles were grouped and representative microplastics in each group of at least 30 particles per site were chosen to test polymer types. This was done as a compromise between labor and cost which was also done by Peng et al., 2017.
Due to size constraints of ATR-FTIR Spectroscopy, it should be noted that only particles with sizes of $500 \mu \mathrm{m}$ and above were analyzed. However, it is assumed that those particles with sizes below $500 \mu \mathrm{m}$ which were subjected to wet peroxide oxidation and density separation are microplastics.

At a resolution of $4 \mathrm{~cm}^{-1}$, thirty-two scans were collected in each sample, and each generated spectrum was documented in the $4,000-400 \mathrm{~cm}^{-1}$ spectral range. The attained spectra were analyzed using the BioRad KnowItAll ${ }^{\oplus}$ Informatics System (2018) software resourced with KnowItAll FTR spectral library that contained an intensive database of known compounds (Horton et al., 2017). For the reliability of data, only those spectra with matching score of more than $70 \%$ with the standard database were accepted (Zhao et al., 2018).

\section{Quality Assurance and Quality Control}

Usage of plastic containers for storage samples was avoided since these may cause additional microplastics in the samples, especially those that are not visible to the naked eye. The containers were properly labelled, stored in a box and transported to the laboratory within the same day for processing. Personal protective equipment like laboratory gowns, safety masks and nitrile gloves were always worn by the investigators during the experiment and analysis.

Collected solids in the glass containers were transferred to a clean beaker using minimal rinsing with squirt bottle containing distilled water, and the beaker was immediately covered with a watch glass to avoid spillage and contamination. Samples stored in glass Petri dishes were always covered to lessen the period of exposure.

The beaker and all the transfer apparatus were washed with distilled water multiple times to minimize any sample loss owing to adhesion of microplastics on the walls of the filter apparatus, and all washing solutions were filtered through the same glassfiber filter. Filters were air dried and subsequently sealed individually in Petri dishes.

The crystal of the ATR-FTIR was cleansed using Kimtech Science Kimwipes and EtOH (96\%) before and after analyzing each particle. Before the start of every FTIR analysis, a blank background scan was tested.

\section{RESULTS AND DISCUSSION}

\section{Abundance of Microplastics}

Microplastics were ubiquitously extracted in both surface water and sediment samples. The abundance of these particles, as illustrated in Figure 2, varied from 1,580-57,665 particles $/ \mathrm{m}^{3}$ in surface waters and 514-1, 357 particles $/ \mathrm{kg}$ in dry sediments.

There is no uniform standard for recording the abundance of microplastics in surface water and sediment worldwide, hence not all the results from published studies can be used for comparison. In this case, only related studies that used similar quantification units (particles $/ \mathrm{m}^{3}$ for surface water; particles/kg of dry weight for sediment) for the abundance of microplastics were gathered as shown in Table 3. Even though these comparisons might be inaccurate because of the differences in the concerned particle 


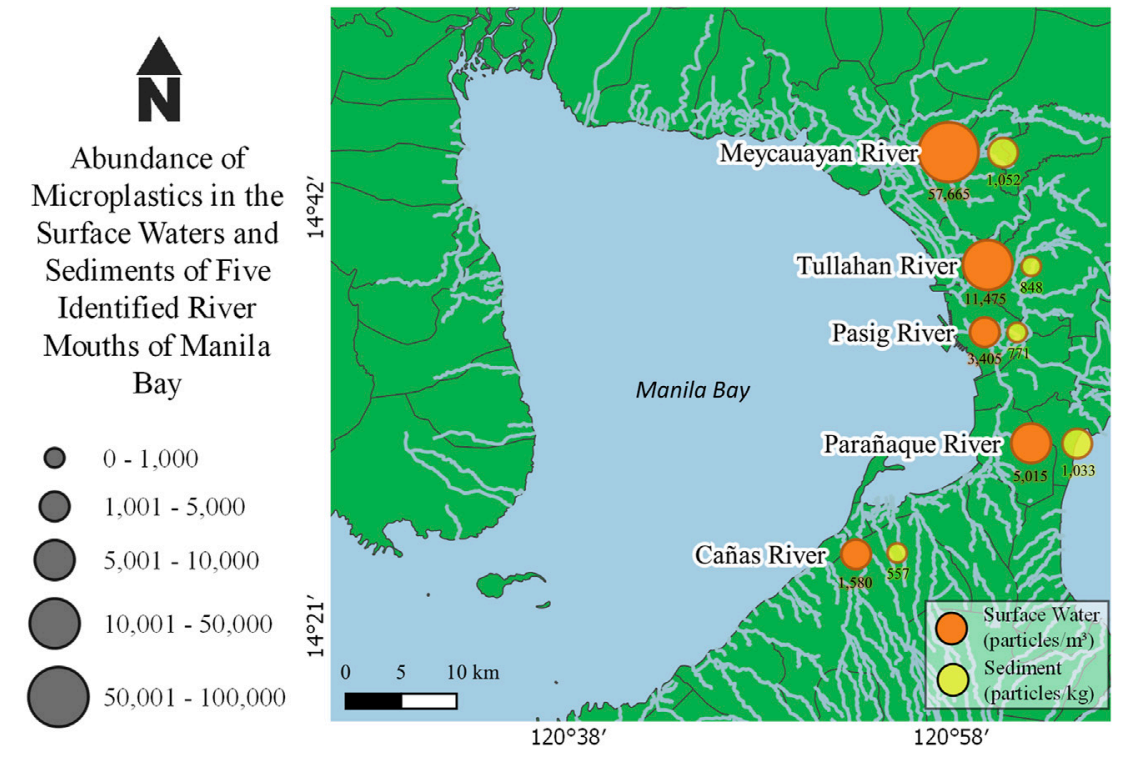

FIGURE 2 | Microplastic abundance in surface waters and sediments of five river mouths in Manila Bay.

size being studied, sampling methodologies, and time and date of sampling, these studies still provide the general overview of the microplastic pollution worldwide (Tanchuling and Osorio, 2020).

Comparison of microplastic particle abundance in surface water across the globe with this study (Table 3 ) indicates a wide variation from as low as 0.73 particles $/ \mathrm{m}^{3}$ in Lake Victoria of Uganda (Egessa et al., 2020) to as high as 30, 800 particles $/ \mathrm{m}^{3}$ in the Winyah Bay of USA (Gray et al., 2018). Generally, the results in this study were relatively higher compared to other studies (Desforges et al., 2014; Zhao et al., 2014; Tsang et al., 2017; Simon-Sánchez et al., 2019; Egessa et al., 2020; Pan et al., 2020; Suresh et al., 2020). As for the Philippine setting, the abundance of microplastics in the surface waters of Meycauayan River and Tullahan River were at higher levels as compared to Tunasan River in Laguna, Lawaye River in Batangas, and creeks in Makati City (Argota et al., 2018; Espiritu et al., 2019; Lumongsod and Tanchuling, 2019).

With regards to the abundance of microplastics in the sediments, the sampling areas had higher levels than previous studies (Ng and Obbard, 2006; Claessens et al., 2011; Liebezeit and Dubaish, 2012; Van Cauwenberghe et al., 2013; Laglbauer et al., 2014; Nor and Obbard, 2014; Zhao et al., 2018) including those studies from the Philippines (Bucol et al., 2019; Espiritu et al., 2019) (Table 3).

\section{Characteristics of Microplastics}

Microplastics are existing in environmental compartments as particles having a variety of colors, shapes, sizes, polymer makeup and even densities (Zhou et al., 2020; Isaac and Kandasubramanian, 2021). These properties were found to be related with the environmental effects and fate of microplastics in the environment (Lambert et al., 2017) and even to the sinking of floating microplastics (Ryan, 2015; Kowalski et al., 2016).
Therefore, the extracted microplastics were classified and quantified according to these properties as shown in Figure 3.

\section{Shape and Polymer Type}

Microplastics were classified according to fragment, film, pellet/ granule, line/fiber, sheet, and foam (Figure 4). These shapes could indicate the parent materials of the microplastics (Zhang et al., 2018).

Fragment as illustrated in Figure 3 is the most dominant shape across all samples. Possible origins of these particles are from the degraded plastic products which include plastic containers, packaging materials and cleaning media (Derraik, 2002; Thompson et al., 2004; Zhang et al., 2015). Most of these fragments were identified as polypropylene (PP) which was the most abundant polymer type identified in most of the representative samples for both surface water and sediment (Figure 3). The abundance of these fragments maybe attributed to indiscriminate waste dumping and mismanaged plastic wastes as evidenced by the amount of macroplastics observed during sampling.

Films were also significantly abundant in all samples especially in the rivers of Cañas and Pasig as the mouth of these two rivers were surrounded by large residential settlements wherein direct littering and rampant garbage dumping were observed. Most films were detected as low-density polyethylene (LDPE) (Figure 3). These films could possibly originate from plastic wrapping, bags and packing materials (Zhang et al., 2015) including single-use plastics, wrappers and sachets observed in each river mouth.

Primary microplastics such as pellets that are mainly used as raw materials for manufactured plastic products (Hidalgo-Ruz et al., 2012; McDermid and McMullen, 2004), were extracted in most of the samples for both surface waters and sediments, indicating the contribution from the industry. These pellets 
TABLE 3 | Mean abundance of microplastics reported in surface water and sediments.

\begin{tabular}{|c|c|c|c|c|}
\hline \multicolumn{2}{|l|}{ Mean abundance } & \multirow[t]{2}{*}{ Study area and country } & \multirow{2}{*}{$\begin{array}{c}\text { Concerned particle size } \\
\qquad 0.3-5 \mathrm{~mm}\end{array}$} & \multirow{2}{*}{$\begin{array}{l}\text { Reference } \\
\text { Egessa et al. (2020) }\end{array}$} \\
\hline Surface Water (particle/m³) & 0.73 & & & \\
\hline & 3.5 & Ebro Estuary (Spain) & $0.005-5 \mathrm{~mm}$ & Simon-Sánchez et al. (2019) \\
\hline & 11 & Deep Bay (Hongkong) & $<5 \mathrm{~mm}$ & Tsang et al. (2017) \\
\hline & 17 & East China Sea (China) & $0.5-5 \mathrm{~mm}$ & Zhao et al. (2014) \\
\hline & 55 & Tsing Yi (Hongkong) & $<5 \mathrm{~mm}$ & Tsang et al. (2017) \\
\hline & 253.1 & Zhangjiang Estuary (China) & $0.330-5 \mathrm{~mm}$ & Pan et al. (2020) \\
\hline & 279 & Northeast Pacific Ocean (Canada) & $<5 \mathrm{~mm}$ & Desforges et al. (2014) \\
\hline & 751.7 & Cochin Estuary (India) & $0.25-5 \mathrm{~mm}$ & Suresh et al. (2020) \\
\hline & 833 & Makati Creeks (Philippines) & $0.3-5 \mathrm{~mm}$ & Lumongsod and Tanchuling (2019) \\
\hline & 1,580 & Cañas River (Philippines) & $0.075-5 \mathrm{~mm}$ & This study \\
\hline & 3,333 & Lawaye River (Philippines) & $0.363-5 \mathrm{~mm}$ & Espiritu et al. (2019) \\
\hline & 3,405 & Pasig River (Philippines) & $0.075-5 \mathrm{~mm}$ & This study \\
\hline & 4,173 & Yangtze Estuary (China) & $0.5-5 \mathrm{~mm}$ & Zhao et al. (2014) \\
\hline & 5,015 & Parañaque River (Philippines) & $0.075-5 \mathrm{~mm}$ & This study \\
\hline & 7,547 & Tunasan River (Philippines) & $0.3-5 \mathrm{~mm}$ & Argota et al. (2018) \\
\hline & 7,630 & Queen Charlotte Sound (Canada) & $<5 \mathrm{~mm}$ & Desforges et al. (2014) \\
\hline & 8,902 & Pearl Estuary (China) & $0.050-5 \mathrm{~mm}$ & Yan et al. (2019) \\
\hline & 9,300 & Haihe River (China) & $0.333-5 \mathrm{~mm}$ & Liu et al. (2020) \\
\hline & 11,475 & Tullahan River (Philippines) & $0.075-5 \mathrm{~mm}$ & This study \\
\hline & 30,800 & Winyah Bay (United States) & $0.063-2 \mathrm{~mm}$ & Gray et al. (2018) \\
\hline & 57,665 & Meycauayan River (Philippines) & $0.075-5 \mathrm{~mm}$ & This study \\
\hline \multirow[t]{21}{*}{ Sediment (particle/kg) } & 1.8 & Beach (Germany) & $<1 \mathrm{~mm}$ & Liebezeit and Dubaish (2012) \\
\hline & 8 & Beach (Singapore) & $1.6 \mu \mathrm{m}-5 \mathrm{~mm}$ & $\mathrm{Ng}$ and Obbard (2006) \\
\hline & 36.8 & Mangrove (Singapore) & $1.6 \mu \mathrm{m}-5 \mathrm{~mm}$ & Nor and Obbard (2014) \\
\hline & 72 & South Yellow Sea Offshore (China) & $1 \mu \mathrm{m}-5 \mathrm{~mm}$ & Zhao et al. (2018) \\
\hline & 75 & Lawaye River (Philippines) & $0.045-5 \mathrm{~mm}$ & Espiritu et al. (2019) \\
\hline & 82 & North Bais Bay (Philippines) & $<2 \mathrm{~mm}$ & Bucol et al. (2019) \\
\hline & 123.6 & North Yellow Sea Offshore (China) & $1 \mu \mathrm{m}-5 \mathrm{~mm}$ & Zhao et al. (2018) \\
\hline & 144 & Beach (Canada) & $<5 \mathrm{~mm}$ & Ballent et al. (2016) \\
\hline & 166.7 & Harbor (Belgium) & $0.038-1 \mathrm{~mm}$ & Claessens et al. (2011) \\
\hline & 171.8 & Bohai Sea Offshore (China) & $1 \mu \mathrm{m}-5 \mathrm{~mm}$ & Zhao et al. (2018) \\
\hline & 177.8 & Beach (Slovenia) & $0.25-5 \mathrm{~mm}$ & Laglbauer et al. (2014) \\
\hline & 557 & Cañas River (Philippines) & $0.075-5 \mathrm{~mm}$ & This study \\
\hline & 760 & Tributary (Canada) & $<5 \mathrm{~mm}$ & Ballent et al. (2016) \\
\hline & 771 & Pasig River (Philippines) & $0.075-5 \mathrm{~mm}$ & This study \\
\hline & 848 & Tullahan River (Philippines) & $0.075-5 \mathrm{~mm}$ & This study \\
\hline & 980 & Nearshore (Canada) & $<5 \mathrm{~mm}$ & Ballent et al. (2016) \\
\hline & 1,033 & Parañaque River (Philippines) & $0.075-5 \mathrm{~mm}$ & This study \\
\hline & 1,052 & Meycauayan River (Philippines) & $0.075-5 \mathrm{~mm}$ & This study \\
\hline & 1,340 & Cochin Estuary (India) & $0.25-5 \mathrm{~mm}$ & Suresh et al. (2020) \\
\hline & $1,423.5$ & Subtidal (Italy) & $0.7 \mu \mathrm{m}-1 \mathrm{~mm}$ & Vianello et al. (2013) \\
\hline & 31,050 & Tidal Flat (Germany) & $<1 \mathrm{~mm}$ & Liebezeit and Dubaish (2012) \\
\hline
\end{tabular}

were identified as high-density polyethylene (HDPE) and could originate from the spillage and personal care products (Fendall and Sewell, 2009; Eerkes-Medrano et al., 2015) (Figure 3). Interestingly, higher number of pellets were extracted from surface waters of Meycauayan River (particle count of 204) compared to the other rivers being studied (particle count of less than 35). Possible origin would be leakage from the plastic manufacturing industries within the watershed of NavotasMalabon-Tenejeros-Tullahan and Marilao-MeycauayanObando River System.

Lines and fibers were also identified in the samples for all sites. These were identified as PP, PE and PET. PET was only identified in the surface water sample of Cañas River while PP and PE were present in all sampling sites (Figure 3). These were probably fragment of plastics originating from fishing nets, ropes, plastic straws and even textiles (Cole et al., 2011; Wang et al., 2017). Aside from garbage dumping and degradation of larger plastics, washing is also considered as an important pathway that releases these lines, fibers, and other airborne particles into the environment (Dris et al., 2016; Salvador Cesa et al., 2017). Numerous fishing activities, aquaculture, and harbors for canoes and bancas present in the sampling areas could be considered as main contributors to the presence of lines and fibers in the samples. The most abundant type in the sediment samples of Parañaque River was line. It is likely due to the existence of large amount of plastic straws, ropes, and fishing nets from the canoes and bancas docked beside the seafood market along the mouth of the river.

Foams mostly polystyrene (PS) were sufficient in amount in the surface waters especially in the rivers of Meycauayan and Tullahan, wherein thousands of foams were extracted (Figure 3). These particles were also identified in the sediments of all study sites in low quantities. It is observed that concentration of PS in surface waters were more abundant than those in the sediments. 

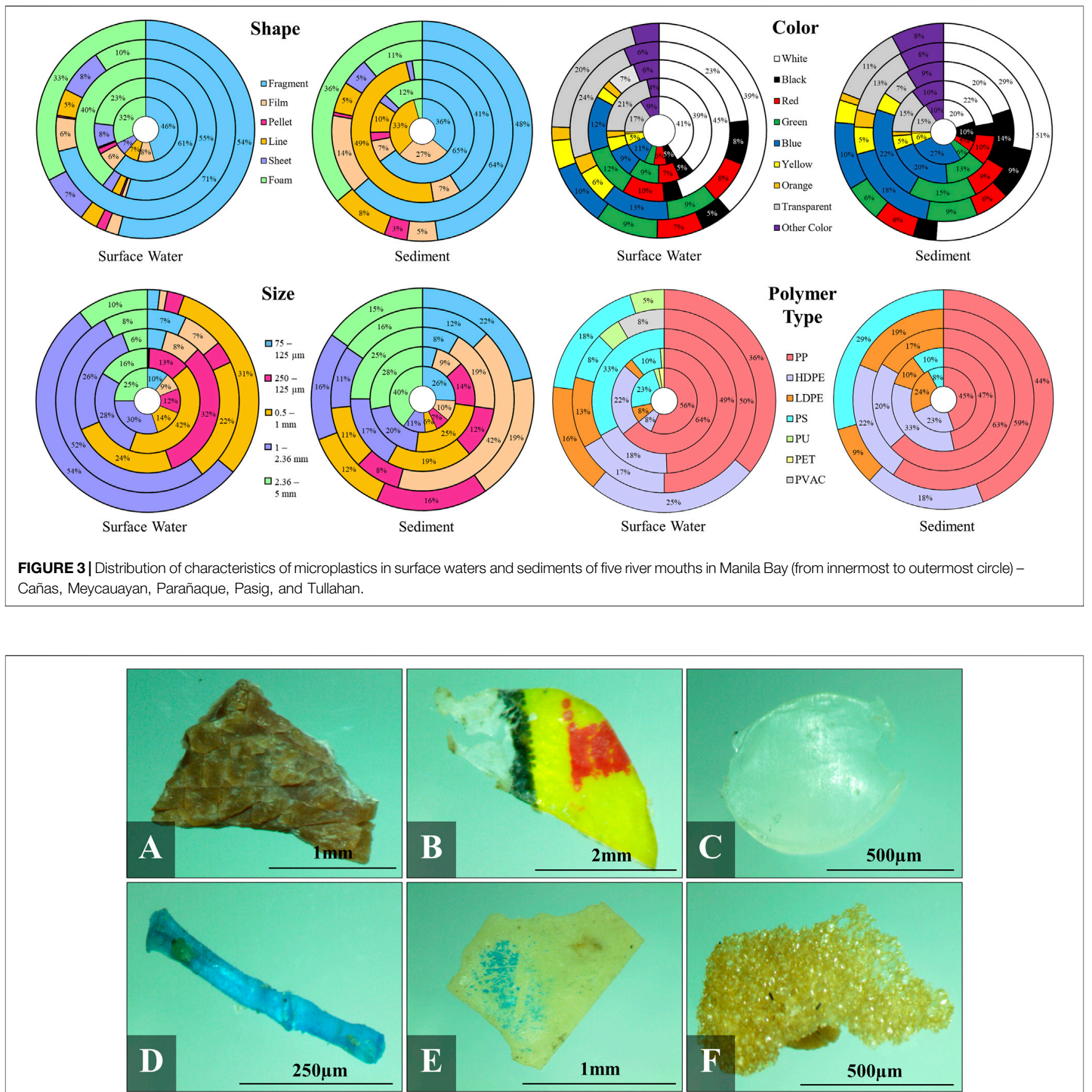

FIGURE 4 | Photographs of different shapes of microplastics collected in all samples: (A) fragment, (B) film, (C) pellet, (D) line, (E) sheet, and (F) foam.

This is likely due to the air injected into the foam, specifically Styrofoam, making it less dense and allowing it to float. Aside from PS, polyurethane (PU) was identified in some foams in the surface waters of Cañas, Meycauayan, Pasig and Tullahan River, but in low quantities only. Site visit and ocular inspection on the sampling areas determined that the possible origin of the foams present in these sites were from large quantities of disposable plastic containers produced such as food and product containers utilized for food delivery services and takeout food, and even from the foam fishing floats and rafts used by fishermen (Di and Wang, 2018).

Significant number of sheets was detected, and these particles were also associated to the degradation of larger plastic products especially for those macroplastics existing in the sampling areas (Cole et al., 2011). Analyzed sheet particles were mostly PP and HDPE. One of the sheets in the surface water sample of Pasig 

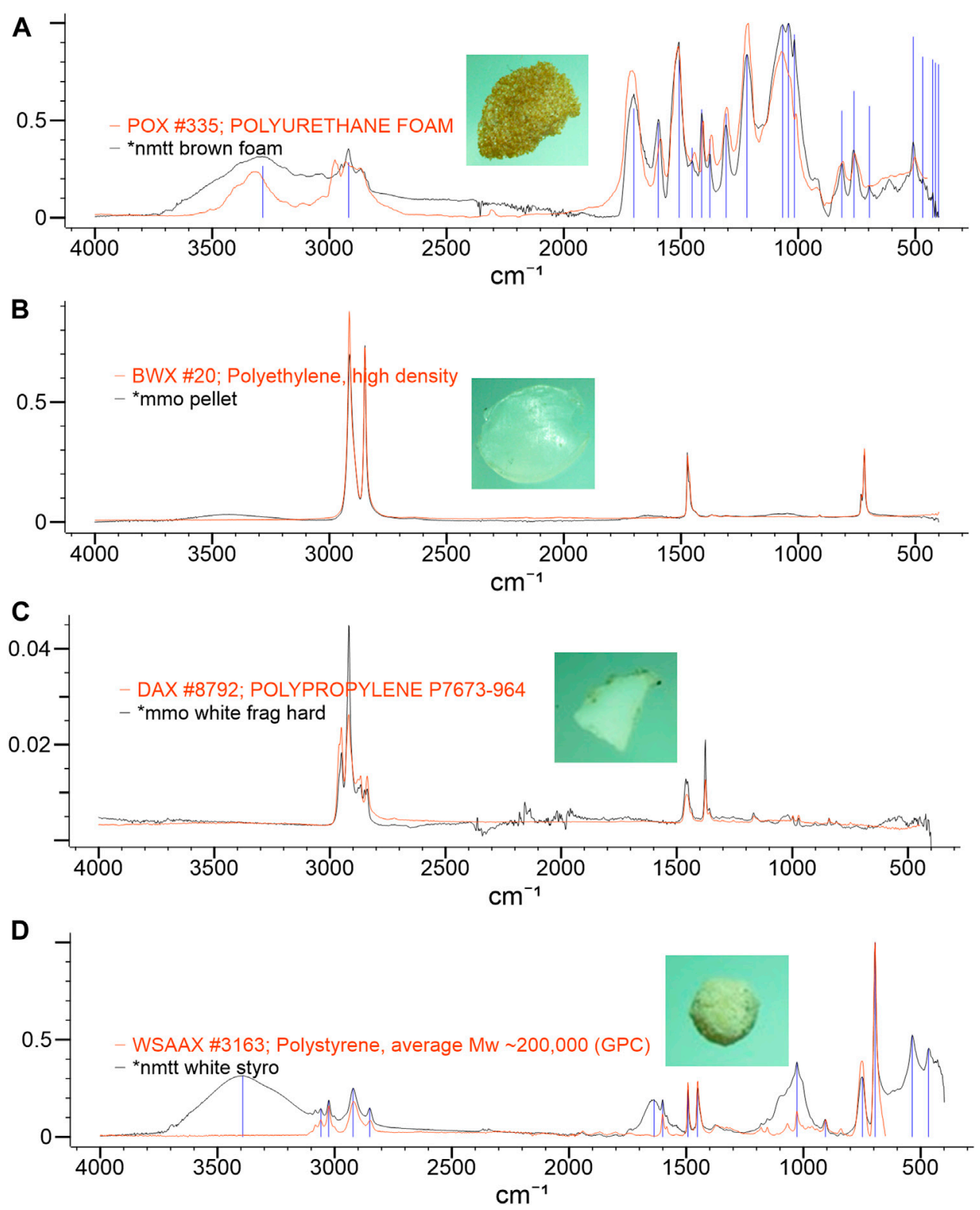

FIGURE 5 | Spectrum for (A) brown foam identified as PU, (B) white pellet identified as HDPE, (C) white fragment identified as PP, and (D) white foam identified as PS.

River was identified as polyvinyl acetate (PVAC) which is primarily used as adhesives for porous materials such as white glue. It is possible that the adhesive material stuck on the particle was identified by ATRFTIR instead of the polymer make-up of the sheet itself.

Low-density polymers including PP, PE, PS and PU particles are expected to float in surface water because their densities are lower as compared to freshwater. However, the polymer types of $\mathrm{PP}$ and PE were the most identified types of plastic among the analyzed samples in the sediments, implying that density is not the only factor affecting the microplastic distribution in the surface waters and sediments. These low-density particles could also be conveyed through current and deposited on the sediments through the following mechanisms: 1$)$ increase in net density of microplastics through biofouling (Andrady, 2011), 2) natural substances adsorption to the surface (Frias et al., 2010), 3) inclusion of inorganic fillers during manufacturing (Corcoran et al., 2015), and 4) fecal express (Cole et al., 2015).

Interestingly, PET whose density is higher than the freshwater was detected in the surface waters of Cañas River even though it is expected to settle down, although in relatively smaller amounts. This might be due to environmental factors such as temperature, wind driven turbulence, tides and waves, these denser plastic particles could have been resuspended from the deeper waters to the surface (Zhao et al., 2014). PET bottles were commonly 


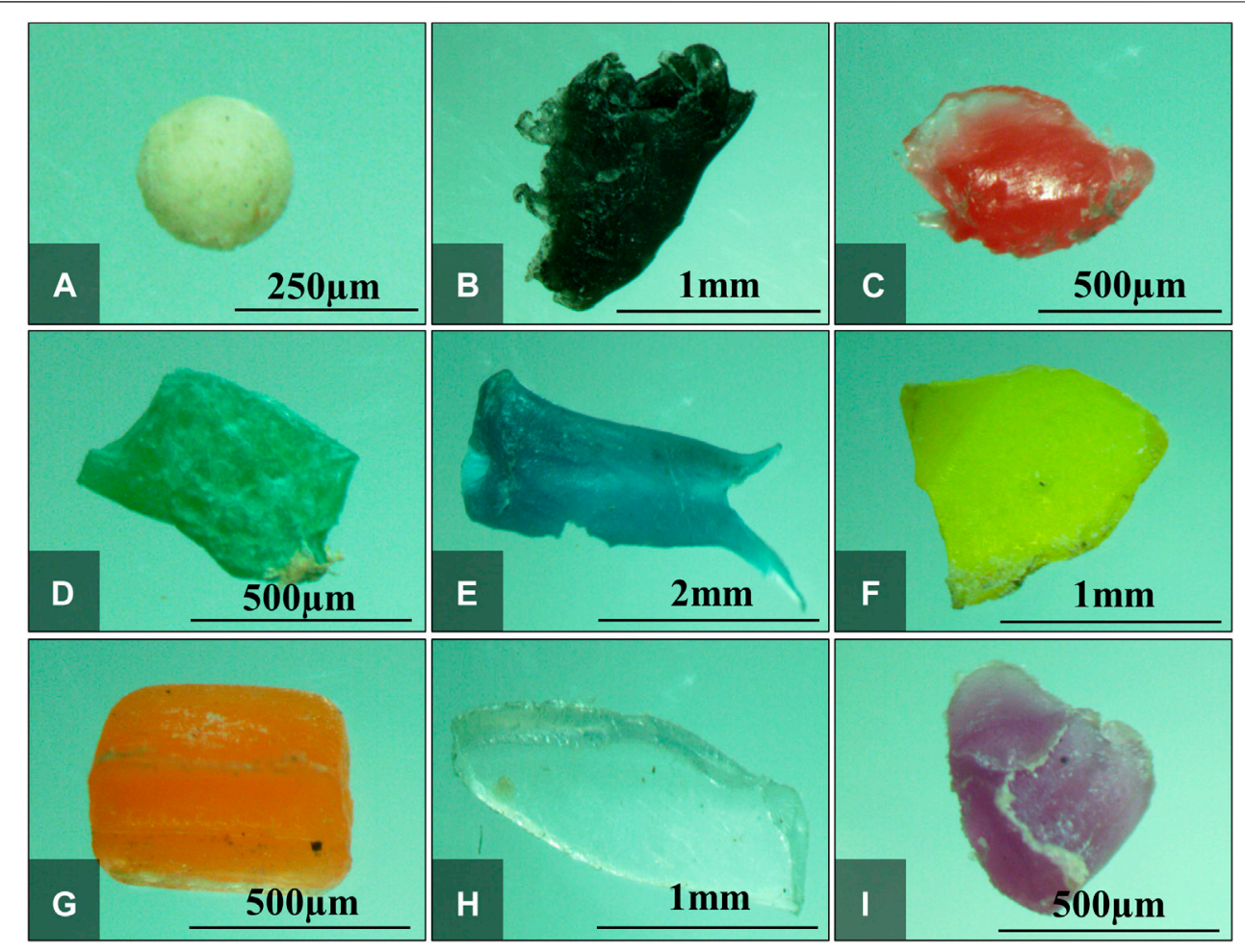

FIGURE 6 | Photographs of different colors of microplastics collected in all samples - (A) white, (B) black, (C) red, (D) green, (E) blue, (F) yellow, (G) orange, (H) transparent, and (I) violet.

collected and sold to junkshops; hence this might be one of the reasons why PET particles were barely identified in the samples.

Spectra were generated for all the analyzed particles. Some of these are shown in Figure 5, and the additional spectral band observed may be associated to the plastic additives or the adsorption of persistent organic pollutants or organic materials (Cole et al., 2011). Further investigation is recommended to identify these specific substances adsorbed to the microplastic samples.

The abundance of the fragments, films, lines and fibers, foams and sheets suggested that majority of the collected microplastics in the mouths of the rivers being studied were locally derived secondary microplastics (Wessel et al., 2016; Yonkos, et al., 2014).

The observed morphological patterns such as scratches, creases, micro-pores, and cracks, among others in the extracted microplastic particles indicate that their source from the degradation of products such as plastic containers, packaging materials, and ropes (Zhang et al., 2016). Moreover, the shape of microplastics were modified by different forces such as the actions from tides and waves (Karthik et al., 2018). Several factors including origins, debris quality, breakdown of plastics, and plastic sinking rate could control the plastic distribution, hence diverse shape distributions in the sampling areas were identified (Critchell and Lambrechts, 2016).

\section{Color}

The microplastic particles were also classified into colors such as red, orange, yellow, green, blue, black, white, transparent, and other colors including violet, brown, and multi-colored particles.
Photographs of typical microplastic samples categorized into different colors of microplastics were presented in Figure 6.

White colored particles may represent the color of plastics such as Styrofoam $^{\mathrm{TM}}$, cap bottles, disposable spoon and fork, and ice cream cups while transparent colored microplastics may come from the virgin pellets, cellophanes, single-use plastics, plastic packing bags and boxes used as food containers. Other identified color particles such as red, green, blue, yellow, orange, violet, and brown were possibly fragmented from commonly used products such as packaging, toys, household products, sachets, plastic straw ropes, and food wrappers. Colored microplastics detected in the environment could be related to the high consumption of the colored plastic products in everyday living (Zhang et al., 2015; Wang et al., 2017).

Color could also be one of the factors for the ingestion of microplastics by marine biota due to resemblance of their prey (Wright et al., 2013). Based on previous studies, it was found out that fish may mistakenly feed on microplastics with colors of white, brown, and yellow that most closely resemble their zooplankton prey (Shaw and Day, 1994; Boerger et al., 2010). Moreover, it was discovered that translucent and light-colored plastics were commonly ingested by sea turtles (Bugoni et al., 2001) and some shapes and colors of plastics were accidentally ingested by some seabirds (Barboza and Gimenez, 2015).

As illustrated in Figure 3, white was the most prevalent color among all surface and sediments samples. This color was also the most observed in Guanabara Bay (Castro et al., 2016) and Northeast Atlantic Ocean (Lusher et al., 2013). These white particles primarily consisted of foams, pellets, and fragments. 


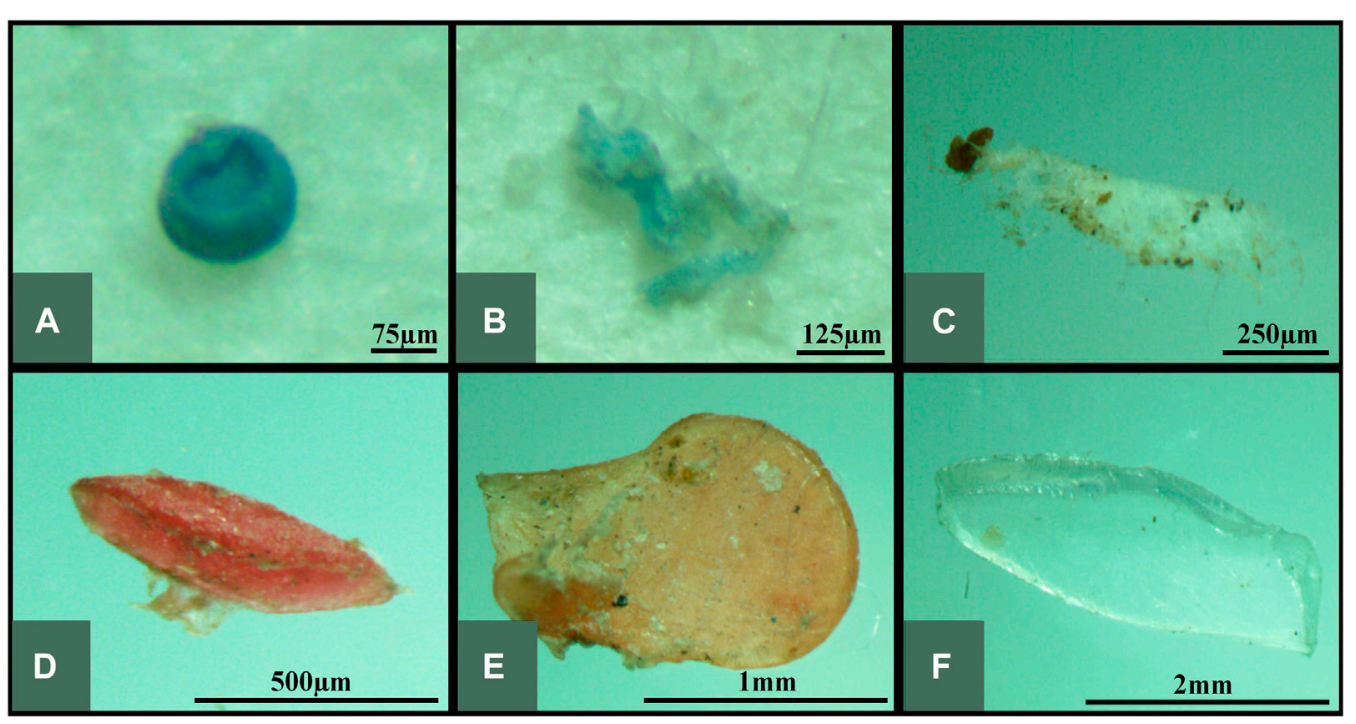

FIGURE 7|Photographs of different sizes of microplastics collected from the surface water and sediment samples - (A) $75-<125 \mu \mathrm{m}$, (B) $125-<250 \mu \mathrm{m}$, (C) 250 $-<500 \mu \mathrm{m}$, (D) $500-<1000 \mu \mathrm{m}$, (E) $1-<2.36 \mathrm{~mm}$, and (F) $2.36-<5 \mathrm{~mm}$.

Most of the plastic pellets extracted from the surface waters and sediments were white and transparent, like previous studies conducted (Turner and Holmes, 2011; Corcoran et al., 2015). This finding is expected since white and transparent pellets are the most common color manufactured (Redford et al., 1997). However, there were very few amounts of black, blue, and orange pellets extracted in some samples, which was also observed by Young and Elliott, 2016.

Transparent and blue were also identified abundantly in all samples. These transparent particles were recognized to be dominant in surface water samples and possibly originated from the short-lifetime and disposable packaging plastic products such as containers, bottles, cups and bags. Furthermore, blue microplastics were mainly comprised of fragments and lines (most probably fishing lines and plastic straws). High prevalence of blue-colored microplastics in the aquatic environment could increase the likelihood of ingestion since some marine fishes reportedly ingested blue microplastics as food (Güven et al., 2017; Ory et al., 2017). Moreover, blue microplastics were also frequently found in clams (Shi, 2018).

Other colored microplastics such as red, green, and yellow were also found in significant amount in the samples as these could be derived from different plastic packaging materials (Zhang et al., 2018). High abundance of colored plastics, especially colored fragments, attributed to the broad usage of coloration in the manufacturing, since coloration is used to attract consumers of plastic products (Thetford et al., 2003).

\section{Size}

It has been reported that microplastic ingestion is primarily determined by size and abundance as compared to color and it occurs by chance (Rodríguez-Sejio and Pereira, 2017). The microplastics could pose risks to the marine biota as demonstrated in fish larvae wherein organisms likely to consume their prey with the smallest dimension (Hunter, 1981). These particles are now considered available for ingestion to aquatic organisms since the sizes of these approximate the size of some planktons (Cole et al., 2011; Wright et al., 2013; Cole et al., 2015). However, due to the differences in the results from published research, further studies are needed to verify which among the attributes of microplastics aid the ingestion.

The extracted particles in this study were classified into six size categories as shown in Figure 7. The lower size limit of microplastics in this study is $75 \mu \mathrm{m}$. Among these different size categories of microplastic particles, the class $1-2.36 \mathrm{~mm}$, contributed the highest quantity in the surface water samples in most of the study sites, except in the rivers of Meycauayan and Parañaque wherein the most abundant size category was $500-1,000 \mu \mathrm{m}$ and $250-500 \mu \mathrm{m}$, respectively (Figure 3).

In general, about $80 \%$ of total microplastics recovered in the samples from surface water were within the size class of $250 \mu \mathrm{m}-5 \mathrm{~mm}$. The size range of these microplastics were still considered visible to the naked eye.

In terms of the microplastic size extracted from the sediment samples, it is observed in Figure 3 that the sizes were relatively evenly distributed in each study site as compared to the distribution of sizes of microplastics collected in the surface water samples. Microplastic particles with size class of $2.36-5 \mathrm{~mm}$, contributed the highest quantity in the sediment samples in most of the study sites, except in the rivers of Pasig and Tullahan wherein the most abundant size category was $125-250 \mu \mathrm{m}$ and $75-125 \mu \mathrm{m}$, respectively. Despite the differences in the percentage distribution of sizes, a significant amount of microplastics was extracted from each size class in each study site. 
Source, Fate and Transport of Microplastics The highest concentration of microplastics for both surface waters and sediments were found to be in Meycauayan River while the lowest was detected in Cañas River (Figure 2). All sampling was done during ebb tide wherein axial convergence occurs near the bottom of the river mouths and axial divergence prevails at the surface making floating matters such as microplastics are pushed towards the banks (Wolanski and Elliot, 2015). This could explain the occurrence of microplastic particles collected in the surface water and sediment along the banks in the mouths of the river sampling.

It could be observed that from south (Cañas River) to north (Meycauayan River), the concentration of microplastics in surface waters tend to increase (Figure 2). The abundance of microplastics in the rivers of Pasig, Tullahan and Meycauayan could be further correlated with the calculated plastic emissions of these rivers from the study of Meijer et al. (2021). This could also be associated with the presence of several plastic manufacturing industries within the watershed of Marilao-Meycauayan-Obando and Navotas-MalabonTenejeros-Tullahan River Systems. This is supported by the presence of pellets which are considered as primary microplastics.

With regards to the wind transport in the bay, individual average wind blow at specific period of the year-controlled bay's circulated gyres differently as simulated by De Las Alas and Sodusta (1985). There are Northeasterly winds, with speeds averaging about $5 \mathrm{~m} / \mathrm{s}$ from October to March and Southwesterly winds, with speeds of $5-7 \mathrm{~m} / \mathrm{s}$ from April to September. Since all sampling were conducted during Northeast monsoon, the effect of winds could possibly contribute to the high abundance of microplastics collected in the rivers of Meycauayan and Tullahan as the direction of the flow of the winds is in counterclockwise direction. While the direction of winds at the southeastern part of the bay where the rivers of Parañaque and Cañas are located is in clockwise direction, the microplastics at their river mouths might be flushed out to the bay.

However, it is recommended to conduct more detailed studies on the combined influence of river runoff, tidal input, coastal currents, and wind transport to the abundance of microplastics in Manila Bay.

In terms of the concentration of microplastics in the sediments, the microplastic pollution levels in sediments from the bay were more closely related to the distance from the contamination source ( $\mathrm{Su}$ et al., 2016) and these microplastic most observed in Guanabara B particles could only be highly disturbed, collected and transported during dredging activities. For example, the amount of microplastics extracted in the sediments in Parañaque River could have possibly originated from the seafood market beside its river mouth.

Based on the study of Siringan and Ringor (1998), the transport direction of surface sediment is southward off Pampanga and northeastward off Cavite. The bottom sediments are always transported from the bay mouth into the bay, and the sediments do not flow from Manila Bay. This would imply that the sediments were more stable as compared to surface water, and the suspended microplastics in the sediments will be transported slower than those floating in surface water (Su et al., 2016).

Manila Bay has a narrow mouth and a relatively weak tidal current, hence the residence time of water inside the bay is relatively longer (Pokavanich and Nadaoka, 2006). It is possible that the microplastics floating in the surface water in each river mouth will be drained off into the bay and will be retained in the bay for a long period of time. These floating microplastics could retain and undergo degradation and be biofouled, making them dense enough to sink (Andrady, 2011; Van Cauwenberghe et al., 2013). This scenario would likely increase not just the concentration of microplastics in the surface waters, but also in the bottom sediments of Manila Bay.

\section{CONCLUSION}

The widespread occurrence in different environmental compartments of microplastics has been recorded worldwide, however, few studies are available on the microplastics present in the aquatic systems in the Philippines. This is the first extensive microplastic study in Manila Bay. This bay serves as an important area for fishing ground and aquaculture activities, hence the occurrence of microplastics in this bay will likely impact on marine organisms and the entire food web through bioaccumulation.

Surface water and sediment samples were collected in the river mouths of Cañas, Meycauayan, Parañaque, Pasig and Tullahan which are draining to Manila Bay. The abundance of microplastics ranges from 580 to 57,665 particles $/ \mathrm{m}^{3}$ in surface water and 386 to 1,357 particles/kg in dry sediment. The levels of microplastic pollution found in these rivers are currently at higher levels, compared to the other studies. Secondary microplastics were found to be the most abundant as fragments indicating that these originate from plastic wastes which were improperly disposed. Therefore, prevention of leakage of both macroplastics and microplastics in the tributary rivers and the bay itself is very important to preserve the marine environment in Manila Bay.

More extensive studies in different waterbodies, and other environmental compartments with sampling in both wet and dry periods to account the effect of seasonal aberration in the abundance and distribution of microplastics are recommended to provide a clear overview on the extent of microplastic pollution in the country. The rehabilitated areas and other tributaries draining to Manila Bay are suggested to be used as sampling areas for further studies to provide more assessment regarding the microplastic contamination in the bay. 


\section{DATA AVAILABILITY STATEMENT}

The raw data supporting the conclusions of this article will be made available by the authors, without undue reservation.

\section{AUTHOR CONTRIBUTIONS}

EO, MT and MD conceived of the idea, developed the methods, and edited the manuscript. EO conducted the experiment and ran analyses. All authors approved

\section{REFERENCES}

Anderson, J. C., Park, B. J., and Palace, V. P. (2016). Microplastics in Aquatic Environments: Implications for Canadian Ecosystems. Environ. Pollut. 218, 269-280. doi:10.1016/j.envpol.2016.06.074

Andrady, A. L. (2011). Microplastics in the marine Environment. Mar. Pollut. Bull. 62 (8), 1596-1605. doi:10.1016/j.marpolbul.2011.05.030

Antunes, J., Frias, J., and Sobral, P. (2018). Microplastics on the Portuguese Coast. Mar. Pollut. Bull. 131, 294-302. doi:10.1016/j.marpolbul.2018.04.025

Argamino, C. R., and Janairo, J. I. B. (2016). Qualitative Assessment and Management of Microplastics in Asian Green Mussels (Perna Viridis) Cultured in Bacoor Bay, Cavite, Phillipines. Environ. Asia 9 (2), 48-54. doi:10.14456/ea.2016.7

Argota, H. L., Bajado, J. A., Diola, M. D., and Tanchuling, M. A. N. (2018). "Macro- and Microplastic Pollution in Tunasan River, Metro Manila, Philippines," in Proceedings of the 4th symposium of the Asian regional branch of international waste working group (IWWG-ARB) 2019, Bangkok, Thailand, 20-22 February 2019.

Ballent, A., Corcoran, P. L., Madden, O., Helm, P. A., and Longstaffe, F. J. (2016). Sources and Sinks of Microplastics in Canadian Lake Ontario Nearshore, Tributary and beach Sediments. Mar. Pollut. Bull. 110 (1), 383-395. doi:10.1016/j.marpolbul.2016.06.037

Barboza, L. G. A., and Gimenez, B. C. G. (2015). Microplastics in the marine Environment: Current Trends and Future Perspectives. Mar. Pollut. Bull. 97, 5-12. doi:10.1016/j.marpolbul.2015.06.008

Biginagwa, F. J., Mayoma, B. S., Shashoua, Y., Syberg, K., and Khan, F. R. (2016). First Evidence of Microplastics in the African Great Lakes: Recovery from Lake Victoria Nile Perch and Nile tilapia. J. Great Lakes Res. 42 (1), 146-149. doi:10.1016/j.jglr.2015.10.012

Boerger, C. M., Lattin, G. L., Moore, S. L., and Moore, C. J. (2010). Plastic Ingestion by Planktivorous Fishes in the North Pacific Central Gyre. Mar. Pollut. Bull. 60, 2275-2278. doi:10.1016/j.marpolbul.2010.08.007

Browne, M. A., Crump, P., Niven, S. J., Teuten, E., Tonkin, A., Galloway, T., et al. (2011). Accumulation of Microplastic on Shorelines Woldwide: Sources and Sinks. Environ. Sci. Technol. 45 (21), 9175-9179. doi:10.1021/es201811s

Browne, M. A., Galloway, T. S., and Thompson, R. C. (2010). Spatial Patterns of Plastic Debris along Estuarine Shorelines. Environ. Sci. Technol. 44, 3404-3409. doi:10.1021/es903784e

Bucol, L. A., Romano, E. F., Cabcaban, S. M., Siplon, L. M. D., Madrid, G. C., Bucol, A. A., et al. (2020). Microplastics in marine Sediments and Rabbitfish (Siganus fuscescens) from Selected Coastal Areas of Negros Oriental, Philippines. Mar. Pollut. Bull. 150, 110685-110694. doi:10.1016/j.marpolbul.2019.110685

Bugoni, L., Krause, L., and Virgı'nia Petry, M. (2001). Marine Debris and Human Impacts on Sea Turtles in Southern Brazil. Mar. Pollut. Bull. 42, 1330-1334. doi:10.1016/s0025-326x(01)00147-3

Carpenter, E. J., Anderson, S. J., Harvey, G. R., Miklas, H. P., and Peck, B. B. (1972). Polystyrene Spherules in Coastal Waters. Science 178, 749-750. doi:10.1126/ science.178.4062.749

Castro, R. O., Silva, M. L., Marques, M. R. C., and de Araújo, F. V. (2016). Evaluation of Microplastics in Jurujuba Cove, Niterói, RJ, Brazil, an Area of Mussels Farming. Mar. Pollut. Bull. 110, 555-558. doi:10.1016/j.marpolbul.2016.05.037

Chang, K. H., Amano, A., Miller, T. W., Isobe, T., Maneja, R., Siringan, F. P., et al. (2009). Pollution Study in Manila Bay: Eutrophication and its Impact on Plankton Community. Interdiscip. Stud. Environ. Chemistry - Environmental Res. Asia, 261-267. the submitted version of the manuscript and agreed to be listed.

\section{FUNDING}

This work was supported by the Engineering Research and Development for Technology (ERDT) grant of the Department of Science and Technology (DOST) and the Office of the Vice Chancellor for Research and Development Outright Research Grant of the University of the Philippines Diliman.

Claessens, M., Meester, S. D., Landuyt, L. V., Clerck, K. D., and Janssen, C. R. (2011). Occurrence and Distribution of Microplastics in marine Sediments along the Belgian Coast. Mar. Pollut. Bull. 62, 2199-2204. doi:10.1016/j.marpolbul.2011.06.030

Cole, M., Lindeque, P., Fileman, E., Halsband, C., and Galloway, T. S. (2015). The Impact of Polystyrene Microplastics on Feeding, Function and Fecundity in the Marine CopepodCalanus Helgolandicus. Environ. Sci. Technol. 49, 1130-1137. doi:10.1021/es504525u

Cole, M., Lindeque, P., Halsband, C., and Galloway, T. S. (2011). Microplastics as Contaminants in the marine Environment: a Review. Mar. Pollut. Bull. 62 (12), 2588-2597. doi:10.1016/j.marpolbul.2011.09.025

Corcoran, P. L., Norris, T., Ceccanese, T., Walzak, M. J., Helm, P. A., and Marvin, C. H. (2015). Hidden Plastics of Lake Ontario, Canada and Their Potential Preservation in the Sediment Record. Environ. Pollut. 204, 17-25. doi:10.1016/j.envpol.2015.04.009

Critchell, K., and Lambrechts, J. (2016). Modelling Accumulation of marine Plastics in the Coastal Zone; what Are the Dominant Physical Processes?. Estuarine, Coastal Shelf Sci. 171, 111-122. doi:10.1016/j.ecss.2016.01.036

De Las Alas, J. G., and Sodusta, J. A. (1985). A Model for the Wind Driven Circulation of Manila Bay. Nat. Appl. Sci. Bull. 37 (2), 159-170.

Derraik, J. G. B. (2002). The Pollution of the marine Environment by Plastic Debris: a Review. Mar. Pollut. Bull. 44, 842-852. doi:10.1016/s0025-326x(02)00220-5

Desforges, J.-P. W., Galbraith, M., Dangerfield, N., and Ross, P. S. (2014). Widespread Distribution of Microplastics in Subsurface Seawater in the NE Pacific Ocean. Mar. Pollut. Bull. 79, 94-99. doi:10.1016/j.marpolbul.2013.12.035

Di, M., and Wang, J. (2018). Microplastics in Surface Waters and Sediments of the Three Gorges Reservoir, China. Sci. Total Environ. 616-617, 1620-1627. doi:10.1016/j.marpolbul.2016.01.00610.1016/j.scitotenv.2017.10.150

Dris, R., Gasperi, J., Saad, M., Mirande, C., and Tassin, B. (2016). Synthetic Fibers in Atmospheric Fallout: a Source of Microplastics in the Environment?. Mar. Pollut. Bull. 104, 290-293. doi:10.1016/j.marpolbul.2016.01.006

Eerkes-Medrano, D., Thompson, R. C., and Aldridge, D. C. (2015). Microplastics in Freshwater Systems: a Review of the Emerging Threats, Identification of Knowledge Gaps and Prioritisation of Research Needs. Water Res. 75, 63-82. doi:10.1016/j.watres.2015.02.012

Egessa, R., Nankabirwa, A., Ocaya, H., and Pabire, W. G. (2020). Microplastic Pollution in Surface Water of Lake Victoria. Sci. Total Environ. 741, 140201. doi:10.1016/j.scitotenv.2020.140201

Eriksen, M., Mason, S., Wilson, S., Box, C., Zellers, A., Edwards, W., et al. (2013). Microplastic Pollution in the Surface Waters of the Laurentian Great Lakes. Mar. Pollut. Bull. 77, 177-182. doi:10.1016/j.marpolbul.2013.10.007

Espiritu, E. Q., Dayrit, S. A. S., Coronel, A. S. O., Paz, N. S. C., Ronquillo, P. I. L., Castillo, V. C. G., et al. (2019). Assessment of Quantity and Quality of Microplastics in the Sediments, Waters, Oysters, and Selected Fish Species in Key Sites along the Bombong Estuary and the Coastal Waters of Ticalan in San Juan, Batangas. Philippine J. Sci. 148 (4), 789-801.

Esquinas, G. G. M. S., Mantala, A. P., Atilano, M. G., Apugan, R. P., and Galarpe, V. R. K. R. (2020). Physical characterization of litter and microplastic along the urban coast of Cagayan de Oro in Macajalar Bay, Philippines. Mar. Pollut. Bull. 154, 111083-111086. doi:10.1016/j.marpolbul.2020.111083

Fendall, L. S., and Sewell, M. A. (2009). Contributing to marine Pollution by Washing Your Face: Microplastics in Facial Cleansers. Mar. Pollut. Bull. 58, 1225-1228. doi:10.1016/j.marpolbul.2009.04.025

Free, C. M., Jensen, O. P., Mason, S. A., Eriksen, M., Williamson, N. J., and Boldgiv, B. (2014). High-levels of Microplastic Pollution in a Large, Remote, mountain lake. Mar. Pollut. Bull. 85, 156-163. doi:10.1016/j.marpolbul.2014.06.001 
Frias, J. P. G. L., Sobral, P., and Ferreira, A. M. (2010). Organic Pollutants in Microplastics from Two Beaches of the Portuguese Coast. Mar. Pollut. Bull. 60, 1988-1992. doi:10.1016/j.marpolbul.2010.07.030

Galarpe, V. R. K. R., Jaraula, C. M. B., and Paler, M. K. O. (2021). The Nexus of Macroplastic and Microplastic Research and Plastic Regulation Policies in the Philippines marine Coastal Environments. Mar. Pollut. Bull. 167, 112343. doi:10.1016/j.marpolbul.2021.112343

Galgani, F., Hanke, G., Werner, S., and De Vrees, L. (2013). Marine Litter within the European Marine Strategy Framework Directive. ICES J. Mar. Sci. 70, 1055-1064. doi:10.1093/icesjms/fst122

Gesamp (2015). "Sources, Fate and Effects of Microplastics in the Marine Environment: A Global Assessment," in IMO/FAO/UNESCO-IOC/UNIDO/ WMO/IAEA/UN/UNEP/UNDP Joint Group of Experts on the Scientific Aspects of Marine Environmental Protection (Rep. Stud. GESAMP No.. London. International Maritime Organization Editor P. J. Kershaw, 90, 96.

Gray, A. D., Wertz, H., Leads, R. R., and Weinstein, J. E. (2018). Microplastic in Two South Carolina Estuaries: Occurrence, Distribution, and Composition. Mar. Pollut. Bull. 128, 223-233. doi:10.1016/j.marpolbul.2018.01.030

Güven, O., Gökdağ, K., Jovanović, B., and Kıdeyş, A. E. (2017). Microplastic Litter Composition of the Turkish Territorial Waters of the Mediterranean Sea, and its Occurrence in the Gastrointestinal Tract of Fish. Environ. Pollut. 223, 286-294. doi:10.1016/j.envpol.2017.01.025

Hidalgo-Ruz, V., Gutow, L., Thompson, R. C., and Thiel, M. (2012). Microplastics in the marine Environment: a Review of the Methods Used for Identification and Quantification. Environ. Sci. Technol. 46 (6), 3060-3075. doi:10.1021/es2031505

Horton, A. A., Svendsen, C., Williams, R. J., Spurgeon, D. J., and Lahive, E. (2017). Large Microplastic Particles in Sediments of Tributaries of the River Thames, UK - Abundance, Sources and Methods for Effective Quantification. Mar. Pollut. Bull. 114 (1), 218-226. doi:10.1016/j.marpolbul.2016.09.004

Hunter, J. R. (1981). Feeding Ecology and Predation of marine Fish Larvae. Morphol. Ecol. Relation Fish., 34-77.

Issac, M. N., and Kandasubramanian, B. (2021). Effect of Microplastics in Water and Aquatic Systems. Environ. Sci. Pollut. Res. 28, 19544-19562. doi:10.1007/s11356021-13184-2

Ivar do Sul, J. A., Spengler, Â., and Costa, M. F. (2009). Here, there and everywhere. Small plastic fragments and pellets on beaches of Fernando de Noronha (Equatorial Western Atlantic). Mar. Pollut. Bull. 58 (8), 1236-1238. doi:10.1016/j.marpolbul.2009.05.004

Jambeck, J. R., Geyer, R., Wilcox, C., Siegler, T. R., Perryman, M., Andrady, A., et al. (2015). Plastic Waste Inputs from Land into the Ocean. Science 347, 768-771. doi:10.1126/science.1260352

Kalnasa, M. L., Lantaca, S. M. O., Boter, L. C., Flores, G. J. T., and Galarpe, V. R. K. R. (2019). Occurrence of Surface Sand Microplastic and Litter in Macajalar Bay, Philippines. Mar. Pollut. Bull. 149, 110521-110524. doi:10.1016/j.marpolbul.2019.110521

Karthik, R., Robin, R. S., Purvaja, R., Ganguly, D., Anandavelu, I., Raghuraman, R., et al. (2018). Microplastics along the Beaches of Southeast Coast of India. Sci. Total Environ. 645, 1388-1399. doi:10.1016/j.scitotenv.2018.07.242

Kowalski, N., Reichardt, A. M., and Waniek, J. J. (2016). Sinking Rates of Microplastics and Potential Implications of Their Alteration by Physical, Biological, and Chemical Factors. Mar. Pollut. Bull. 109, 310-319. doi:10.1016/ j.marpolbul.2016.05.064

Laglbauer, B. J. L., Franco-Santos, R. M., Andreu-Cazenave, M., Brunelli, L., Papadatou, M., Palatinus, A., et al. (2014). Macrodebris and Microplastics from Beaches in Slovenia. Mar. Pollut. Bull. 89, 356-366. doi:10.1016/j.marpolbul.2014.09.036

Lambert, S., Scherer, C., and Wagner, M. (2017). Ecotoxicity Testing of Microplastics: Considering the Heterogeneity of Physicochemical Properties. Integr. Environ. Assess. Manag. 13, 470-475. doi:10.1002/ieam.1901

Law, K. L., Starr, N., Siegler, T. R., Jambeck, J. R., Mallos, N. J., and Leonard, G. H. (2020). The United States' Contribution of Plastic Waste to Land and Ocean. Sci. Adv. 6 (44), 1-7. doi:10.1126/sciadv.abd0288

Li, D., Xu, Y., Li, Y., Wang, J., Yin, X., Ye, X., et al. (2018). Sedimentary Records of Human Activity and Natural Environmental Evolution in Sensitive Ecosystems: a Case Study of a Coral Nature reserve in Dongshan Bay and a Mangrove forest Nature reserve in Zhangjiang River Estuary, Southeast China. Org. Geochem. 121, 22-35. doi:10.1016/j.orggeochem.2018.02.011

Li, J., Liu, H., and Paul Chen, J. (2018). Microplastics in Freshwater Systems: A Review on Occurrence, Environmental Effects, and Methods for Microplastics Detection. Water Res. 137, 362-374. doi:10.1016/j.watres.2017.12.056
Li, J., Qu, X., Su, L., Zhang, W., Yang, D., Kolandhasamy, P., et al. (2016). Microplastics in Mussels along the Coastal Waters of China. Environ. Pollut. 214, 177-184. doi:10.1016/j.envpol.2016.04.012

Liebezeit, G., and Dubaish, F. (2012). Microplastics in Beaches of the East Frisian Islands Spiekeroog and Kachelotplate. Bull. Environ. Contam. Toxicol. 89 (1), 213-217. doi:10.1007/s00128-012-0642-7

Lima, A. R. A., Barletta, M., and Costa, M. F. (2015). Seasonal Distribution and Interactions between Plankton and Microplastics in a Tropical Estuary. Estuarine, Coastal Shelf Sci. 165, 213-225. doi:10.1016/j.ecss.2015.05.018

Ling, S. D., Sinclair, M., Levi, C. J., Reeves, S. E., and Edgar, G. J. (2017). Ubiquity of Microplastics in Coastal Seafloor Sediments. Mar. Pollut. Bull. 121 (5), 104-110. doi:10.1016/j.marpolbul.2017.05.038

Liu, Y., Zhang, J., Cai, C., He, Y., Chen, L., Xiong, X., et al. (2020). Occurrence and Characteristics of Microplastics in the Haihe River: An Investigation of a Seagoing River Flowing through a Megacity in Northern China. Environ. Pollut. 262, 114261. doi:10.1016/j.envpol.2020.114261

Lumongsod, S. L. R., and Tanchuling, M. A. N. (2019). "Microplastic Characterization and Analysis in Three Makati City Creeks," in Proceedings on the 4th symposium of the international waste working group-Asian regional board (IWWG-ARB) 2019, Bangkok, Thailand, 20-22 February 2019.

Lusher, A. L., McHugh, M., and Thompson, R. C. (2013). Occurrence of Microplastics in the Gastrointestinal Tract of Pelagic and Demersal Fish from the English Channel. Mar. Pollut. Bull. 67, 94-99. doi:10.1016/j.marpolbul.2012.11.028

Masura, J., Baker, J., Foster, G., and Arthur, C. (2015). Laboratory Methods for Analysis of Microplastics in the marine Environment: Recommendations for Quantifying Synthetic Particles in Waters and Sediments. Maryland: NOAA Marine Debris Division.

McDermid, K. J., and McMullen, T. L. (2004). Quantitative Analysis of SmallPlastic Debris on Beaches in the Hawaiian Archipelago. Mar. Pollut. Bull. 48, 790-794. doi:10.1016/j.marpolbul.2003.10.017

Meijer, L. J. J., van Emmerik, T., van der Ent, R., Schmidt, C., and Lebreton, L. (2021). More Than 1000 Rivers Account for $80 \%$ of Global Riverine Plastic Emissions into the Ocean. Sci. Adv. 7 (18), 1-13. doi:10.1126/sciadv.aaz5803

Mohamed Nor, N. H., and Obbard, J. P. (2014). Microplastics in Singapore's Coastal Mangrove Ecosystems. Mar. Pollut. Bull. 79, 278-283. doi:10.1016/ j.marpolbul.2013.11.025

Ng, K. L., and Obbard, J. P. (2006). Prevalence of Microplastics in Singapore's Coastal marine Environment. Mar. Pollut. Bull. 52, 761-767. doi:10.1016/ j.marpolbul.2005.11.017

Obbard, R. W., Sadri, S., Wong, Y. Q., Khitun, A. A., Baker, I., and Thompson, R. C. (2014). Global Warming Releases Microplastic Legacy Frozen in Arctic Sea Ice. Earth's Future 2, 315-320. doi:10.1002/2014EF000240

Ory, N. C., Sobral, P., Ferreira, J. L., and Thiel, M. (2017). Amberstripe Scad Decapterus Muroadsi (Carangidae) Fish Ingest Blue Microplastics Resembling Their Copepod Prey along the Coast of Rapa Nui (Easter Island) in the South Pacific Subtropical Gyre. Sci. Total Environ. 586, 430-437. doi:10.1016/ j.scitotenv.2017.01.175

Paler, M. K. O., Leistenschneider, C., Migo, V., and Burkhardt-Holm, P. (2021). Low Microplastic Abundance in Siganus Spp. From the Tañon Strait, Central Philippines. Environ. Pollut. 284, 117166-117169. doi:10.1016/j.envpol.2021.117166

Pan, Z., Sun, Y., Liu, Q., Lin, C., Sun, X., He, Q., et al. (2020). Riverine Microplastic Pollution Matters: A Case Study in the Zhangjiang River of Southeastern China. Mar. Pollut. Bull. 159, 111516. doi:10.1016/j.marpolbul.2020.111516

PEMSEA, and MBEMP TWG-RRA (2004). "Manila Bay: Refined Risk Assessment. PEMSEA Technical Report No. 9. Global Environment Facility/United Nations Development Programme/International Maritime Organization Regional Programme on Building Partnerships in Environmental Management for the Seas of East Asia (PEMSEA), and Manila Bay Environmental Management Project (MBEMP), Technical Working Group for Refined Risk Assessment (TWG- RRA)," in Quezon City, Philippines: GEF/UNDP/IMO Regional Programme on Building Partnerships in Environmental Management for the Seas of East Asia. Quezon City. GEF/UNDP/IMO PEMSEA and MBEMP, 69.

Peng, G., Zhu, B., Yang, D., Su, L., Shi, H., and Li, D. (2017). Microplastics in Sediments of the Changjiang Estuary, China. Environ. Pollut. 225, 283-290. doi:10.1016/j.envpol.2016.12.064

Pokavanich, T., and Nadaoka, K. (2006). Three-Dimensional Hydrodynamics Simulation of Manila Bay. Symposium on Infrastructure Development and 
the Environment [Preprint]. Available at: http://www.wv.mei.titech.ac.jp/ IMSWES07/files/pokavanich_MB.pdf (Accessed February 23, 2019).

Prudente, M. S., Ichihashi, H., and Tatsukawa, R. (1994). Heavy Metal Concentrations in Sediments from Manila Bay, Philippines and Inflowing Rivers. Environ. Pollut. 86, 83-88. doi:10.1016/0269-7491(94)90009-4

Redford, D. P., Trulli, H. K., and Trulli, W. R. (1997). Sources of Plastic Pellets in the Aquatic Environment. Springer-Verlag 25, 335-343. doi:10.1007/978-1-4613-8486-1_30

Rodríguez-Seijo, A., and Pereira, R. (2017). "Morphological and Physical Characterization of Microplastics", in Comprehensive Analytical Chemistry Series (Amsterdam: Elsevier), 49-66. doi:10.1016/bs.coac.2016.10.007

Ryan, P. G. (2015). Does Size and Buoyancy Affect the Long-Distance Transport of Floating Debris? Environ. Res. Lett. 10, 6. doi:10.1088/1748-9326/10/8/084019

Salvador Cesa, F., Turra, A., and Baruque-Ramos, J. (2017). Synthetic Fibers as Microplastics in the marine Environment: a Review from Textile Perspective with a Focus on Domestic Washings. Sci. Total Environ. 598, 1116-1129. doi:10.1016/j.scitotenv.2017.04.172

Sanchez, W., Bender, C., and Porcher, J.-M. (2014). Wild Gudgeons (Gobio gobio) from French Rivers Are Contaminated by Microplastics: Preliminary Study and First Evidence. Environ. Res. 128, 98-100. doi:10.1016/j.envres.2013.11.004

Shaw, D. G., and Day, R. H. (1994). Colour- and Form-dependent Loss of Plastic Micro-debris from the North Pacific Ocean. Mar. Pollut. Bull. 28 (1), 39-43. doi:10.1016/0025-326X(94)90184-8

Sia, S. G. L., Martillano, K. J., Alcantara, T. P., Ragragio, E., De Jesus, J., Hallare, A., et al. (2009). Assessing Heavy Metals in the Waters, Fish, and Macroinvertebrates in Manila Bay, Philippines. J. Appl. Sci. Environ. Sanitation 4 (3), 187-195.

Simon-Sánchez, L., Grelaud, M., Garcia-Orellana, J., and Ziveri, P. (2019). River Deltas as Hotspots of Microplastic Accumulation: the Case Study of the Ebro River (NW Mediterranean). Sci. Total Environ. 687, 1186-1196. doi:10.1016/ j.scitotenv.2019.06.168

Siringan, F., and Ringor, C. (1998). Changes in Bathymetry and Their Implications to Sediment Dispersal and Rates of Sedimentation in Manila Bay. Sci. Diliman 10 (2), 12-26.

Su, L., Cai, H., Kolandhasamy, P., Wu, C., Rochman, C. M., and Shi, H. (2018). Using the Asian Clam as an Indicator of Microplastic Pollution in Freshwater Ecosystems. Environ. Pollut. 234, 347-355. doi:10.1016/j.envpol.2017.11.075

Su, L., Xue, Y., Li, L., Yang, D., Kolandhasamy, P., Li, D., et al. (2016). Microplastics in Taihu Lake, China. Environ. Pollut. 216, 711-719. doi:10.1016/j.envpol.2016.06.036

Suresh, A., Vijayaraghavan, G., K.S., S., K.V., N., B., A., and S., B. N. (2020). Microplastics Distribution and Contamination from the Cochin Coastal Zone, India. Reg. Stud. Mar. Sci. 40, 101533. doi:10.1016/j.rsma.2020.101533

Tanchuling, M. A. N., and Osorio, E. D. (2020). "The Microplastics in Metro Manila Rivers: Characteristics, Sources, and Abatement," in The Handbook of Environmental Chemistry. Editors F. Stock, G. Reifferscheid, N. Brennholt, and E. Kostianaia (Quezon City: Springer), 1-22. doi:10.1007/698_2020_659

Thetford, D., Chorlton, A., and Hardman, J. (2003). Synthesis and Properties of Some Polycyclic Barbiturate Pigments. Dyes Pigm. 59, 185-191. doi:10.1016/ S0143-7208(03)00104-9

Thompson, R. C., Olsen, Y., Mitchell, R. P., Davis, A., Rowland, S. J., John, A. W. G., et al. (2004). Lost at Sea: where Is All the Plastic? Science 304, 838. doi:10.1126/ science. 1094559

Tsang, Y. Y., Mak, C. W., Liebich, C., Lam, S. W., Sze, E. T.-P., and Chan, K. M. (2017). Microplastic Pollution in the marine Waters and Sediments of Hong Kong. Mar. Pollut. Bull. 115 (1-2), 20-28. doi:10.1016/j.marpolbul.2016.11.003

Turner, A., and Holmes, L. (2011). Occurrence, Distribution and Characteristics of Beached Plastic Production Pellets on the Island of Malta (central Mediterranean). Mar. Pollut. Bull. 62, 377-381. doi:10.1016/j.marpolbul.2010.09.027

Van Cauwenberghe, L., Claessens, M., Vandegehuchte, M. B., Mees, J., and Janssen, C. R. (2013). Assessment of marine Debris on the Belgian Continental Shelf. Mar. Pollut. Bull. 73, 161-169. doi:10.1016/j.marpolbul.2013.05.026

Van Cauwenberghe, L., Devriese, L., Galgani, F., Robbens, J., and Janssen, C. R. (2015). Microplastics in Sediments: a Review of Techniques, Occurrence and Effects. Mar. Environ. Res. 111, 5-17. doi:10.1016/j.marenvres.2015.06.007

Vianello, A., Boldrin, A., Guerriero, P., Moschino, V., Rella, R., Sturaro, A., et al. (2013). Microplastic Particles in Sediments of Lagoon of Venice, Italy: First Observations on Occurrence, Spatial Patterns and Identification. Estuarine, Coastal Shelf Sci. 130, 54-61. doi:10.1016/j.ecss.2013.03.022

Wang, T., Li, B., Zou, X., Wang, Y., Li, Y., Xu, Y., et al. (2019). Emission of Primary Microplastics in mainland China: Invisible but Not Negligible. Water Res. 162, 214-224. doi:10.1016/j.watres.2019.06.042
Wang, W., Ndungu, A. W., Li, Z., and Wang, J. (2017). Microplastics Pollution in Inland Freshwaters of China: a Case Study in Urban Surface Waters of Wuhan, China. Sci. Total Environ. 575, 1369-1374. doi:10.1016/ j.scitotenv.2016.09.213

Wessel, C. C., Lockridge, G. R., Battiste, D., and Cebrian, J. (2016). Abundance and Characteristics of Microplastics in beach Sediments: Insights into Microplastic Accumulation in Northern Gulf of Mexico Estuaries. Mar. Pollut. Bull. 109, 178-183. doi:10.1016/j.marpolbul.2016.06.002

Wolanski, E., and Elliott, M. (2015). "Estuarine Water Circulation," in In Estuarine Ecohydrology. Editors E. Wolanski and M. Elliott. 2nd edition (Amsterdam: Elsevier), 17-39. doi:10.1016/B978-044453066-0.50003-9

Wright, S. L., Thompson, R. C., and Galloway, T. S. (2013). The Physical Impacts of Microplastics on marine Organisms: A Review. Environ. Pollut. 178, 483-492. doi:10.1016/j.envpol.2013.02.031

Yan, M., Nie, H., Xu, K., He, Y., Hu, Y., Huang, Y., et al. (2019). Microplastic Abundance, Distribution and Composition in the pearl river along Guangzhou City and pearl river Estuary, China. Chemosphere 217, 879-886. doi:10.1016/ j.chemosphere.2018.11.093

Yonkos, L. T., Friedel, E. A., Perez-Reyes, A. C., Ghosal, S., and Arthur, C. D. (2014). Microplastics in Four Estuarine Rivers in the Chesapeake Bay, U.S.A. Environ. Sci. Technol. 48, 14195-14202. doi:10.1021/es5036317

Young, A. M., and Elliott, J. A. (2016). Characterization of Microplastic and Mesoplastic Debris in Sediments from Kamilo Beach and Kahuku Beach, Hawai' i. Mar. Pollut. Bull. 113 (1-2), 477-482. doi:10.1016/ j.marpolbul.2016.11.009

Zarfl, C., and Matthies, M. (2010). Are marine Plastic Particles Transport Vectors for Organic Pollutants to the Arctic?. Mar. Pollut. Bull. 60 (10), 1810-1814. doi:10.1016/j.marpolbul.2010.05.026

Zhang, H. (2017). Transport of Microplastics in Coastal Seas. Estuarine, Coastal Shelf Sci. 199, 74-86. doi:10.1016/j.ecss.2017.09.032

Zhang, K., Gong, W., Lv, J., Xiong, X., and Wu, C. (2015). Accumulation of Floating Microplastics behind the Three Gorges Dam. Environ. Pollut. 204, 117-123. doi:10.1016/j.envpol.2015.04.023

Zhang, K., Shi, H., Peng, J., Wang, Y., Xiong, X., Wu, C., et al. (2018). Microplastic Pollution in China's Inland Water Systems: A Review of Findings, Methods, Characteristics, Effects, and Management. Sci. Total Environ. 630, 1641-1653. doi:10.1016/j.scitotenv.2018.02.300

Zhang, K., Su, J., Xiong, X., Wu, X., Wu, C., and Liu, J. (2016). Microplastic Pollution of Lakeshore Sediments from Remote Lakes in Tibet Plateau, China. Environ. Pollut. 219, 450-455. doi:10.1016/j.envpol.2016.05.048

Zhao, J., Ran, W., Teng, J., Liu, Y., Liu, H., Yin, X., et al. (2018). Microplastic Pollution in Sediments from the Bohai Sea and the Yellow Sea, China. Sci. Total Environ. 640-641, 637-645. doi:10.1016/j.scitotenv.2018.05.346

Zhao, S., Zhu, L., Wang, T., and Li, D. (2014). Suspended Microplastics in the Surface Water of the Yangtze Estuary System, China: First Observations on Occurrence, Distribution. Mar. Pollut. Bull. 86 (1-2), 562-568. doi:10.1016/ j.marpolbul.2014.06.032

Zhou, Y., Wang, J., Zou, M., Jia, Z., Zhou, S., and Li, Y. (2020). Microplastics in Soils: A Review of Methods, Occurrence, Fate, Transport, Ecological and Environmental Risks. Sci. Total Environ. 748, 141368. doi:10.1016/j.scitotenv.2020.141368

Conflict of Interest: The authors declare that the research was conducted in the absence of any commercial or financial relationships that could be construed as a potential conflict of interest.

Publisher's Note: All claims expressed in this article are solely those of the authors and do not necessarily represent those of their affiliated organizations, or those of the publisher, the editors and the reviewers. Any product that may be evaluated in this article, or claim that may be made by its manufacturer, is not guaranteed or endorsed by the publisher.

Copyright (๑) 2021 Osorio, Tanchuling and Diola. This is an open-access article distributed under the terms of the Creative Commons Attribution License (CC BY). The use, distribution or reproduction in other forums is permitted, provided the original author(s) and the copyright owner(s) are credited and that the original publication in this journal is cited, in accordance with accepted academic practice. No use, distribution or reproduction is permitted which does not comply with these terms. 